\title{
Spectrum of Asthma in Children-II, Allergic Components
}

\author{
K. N. MCNICHOL， H. E. WILLIAMS
}

British Medical fournal, 1973, 4, 12-16

\begin{abstract}
Summary
The incidence of a variety of clinical and immunological features of an allergic state was studied at 7,10 , and 14 years of age in a group of children suffering from one of four grades of asthma, ranging from mild subclinical to severe unremitting, and compared with the incidence in a control group of non-asthmatic children. The incidence of all features of allergy was significantly higher in the asthmatics but no one feature unequivocally distinguished the asthmatics from the controls. Almost all the asthmatics showed several features of the allergic state at 14 years of age. A cluster of allergic features was a differentiating characteristic of the asthmatics, and the children with the most allergic manifestations were usually the children with the most severe and persistent asthma. The first appearance of and subsequent variation in some of the allergic manifestations often did not correspond to the clinical course of the asthma.

Though many manifestations of asthma can be understood on an allergic basis the mechanism by which emotional disturbance, exercise, viral infections, and non-allergenic stimuli precipitate attacks of asthma and the relation of these factors to allergy are unknown.
\end{abstract}

\section{Introduction}

In this paper the term allergy refers to an altered immunological state of type I (immediate) hypersensitivity reaction (Gell and Coombs, 1968). The recent isolation and identification of specific reaginic antibodies (IgE) in the serum of many asthmatic children has extended knowledge of the immunology of asthma (Ishizaka and Ishizaka, 1970). Studies of mechanisms by which antigen-reaginic combinations may cause asthma and of the way these reactions can be blocked by disodium cromoglycate further point to the importance of an immunological disorder as a basic factor in asthma.

Type I hypersensitivity to common grass pollens and to the house-dust mite has been claimed as an important mechanism in childhood asthma, because the high levels of specific IgE antibodies in the serum of these children show significant correlations not only with prick and provocation tests with corresponding specific allergens but also with the clinical history (Stenuis et al., 1971). But it is not clear whether all children with asthma have an underlying allergic disorder (Vries et al., 1964). There are other well-known precipitating causes of asthmatic attacks such as emotional factors, viral infection, exercise, and other non-specific stimuli.

In an earlier report of this epidemiological study up to 10 years of age (Williams and $\mathrm{McNicol}, 1969$ ) a comparison of the the incidence of a range of clinical and immunological features of allergy in children with "asthma" and children with "wheezy bronchitis" showed a similar pattern in each. This and other findings strongly suggested that the two conditions were different

\footnotetext{
Clinical Research Unit, Royal Children's Hospital, Melbourne, Australia

K. N. MCNICOL, M.D., Research Fellow

K. N. MCNICOL, M.D., Research Fellow
H. E. WILLIAMS, M.D., F.R.A.C.P., Director
}

manifestations of the same disease. This paper compares the incidence of a range of clinical and immunological features of allergy in a representative sample of asthmatic and control children at 7, 10, and 14 years of age. It also compares the distribution of these allergic features among the asthmatic children in four groups graded according to the frequency and persistence of their asthma.

\section{Subjects and Methods}

The children studied were the asthmatic and control subjects of a longitudinal epidemiological study of asthma in Melbourne children described in the first of these three papers (McNicol and Williams, 1973a). This also described the patterns of asthma in each of the four grades and the relative incidence of various features on which severity was assessed.

Hay fever was defined as episodes of itching or irritation of the nasal mucous membrane, with sneezing and increased nasal mucous secretion, either seasonal in character or provoked by exposure to specific allergens. It was graded,+++ , or +++ according to the frequency and severity of the attacks.

Eczema was defined as scaly, red, itchy lesions usually in flexural folds of the limbs or face and trunk. The condition was graded,+++ , or +++ on the extent and duration of the lesions and whether there were constitutional symptoms.

Urticaria included hives; generalized, irregular weal-like lesions to angioneurotic oedema; serum sickness; or anaphylactic reactions and was graded,+++ , or +++ on the extent, frequency, and duration of the lesions and whether constitutional symptoms were present.

Skin Sensitivity Tests.-Standard scratch tests were done on the anterior aspect of the forearm with each of six standard allergen extracts and a control extract fluid at 7,10 , and 14 years of age, results being recorded as $\mathrm{O},+,++$, or +++ . The extracts used were three standard specific extracts-rye grass, house dust, and egg albumen (Commonwealth Serum Laboratories, Parkville, Victoria) - and three mixed extracts specially prepared by Commonwealth Serum Laboratories, which included most of the proteins commonly associated with clinical allergic manifestations in Melbourne children. The mixed grass pollens extract contained cocksfoot, rye, and Yorkshire fog grass pollen and capeweek, dock, and plantain pollens. The mixed inhalant extract included cat hair, house dust, kapok, linseed, orris root, and cladosporium allergens. The mixed food extract contained egg albumen, cows' milk, orange, and wheat flour allergens.

A subgroup of children in each grade were also tested with a number of specific allergens at the third examination at 14 years of age and the findings were compared with those of radioallergosorbent tests for each of the reagins specific for the allergens studied (Hogarth-Scott et al., 1973).

Investigations of Eosinophil Responses.-At 7, 10, and 14 years the blood and a nasal smear were examined for eosinophils in all subjects. Blood eosinophil counts were expressed as an absolute count per $\mathrm{mm}^{3}$ and nasal eosinophils were reported on a fourpoint scale: (1) no eosinophils seen; (2) mild eosinophilialess than $5 \%$ of the cells seen; (3) moderate eosinophilia$5-20 \%$ of the cells seen; and (4) severe eosinophilia-more than $20 \%$ of the cells seen.

Serum Histaminopexy.-The histamine-binding capacity of the serum was investigated at 10 years of age in about $90 \%$ of the children by a latex precipitation test developed by Mikol et al. (1961) and modified by Freeman (1969). The capacity of 
the serum to bind histamine was reported as positive, weakly positive, or negative.

Serum IgE Assay.- Radioimmunosorbent tests for total serum IgE were carried out at 10 years of age on 37 of the control children and on 133 of the asthmatic children from the four grades (Hogarth-Scott et al., 1971) and at 14 years of age on 43 of the severely affected, predominantly grade $\mathrm{D}$ children (Hogarth-Scott et al., 1973).

\section{Results}

The prevalence; natural history, including the age at onset; duration; and severity of hay fever, eczema, and urticaria in the four grades of asthmatic children and in the controls are summarized in tables I-III. The prevalence of hay fever in al grades of asthmatic children was significantly higher than in the controls, the highest frequency and most severe pattern being, found in grades C and D (table I). Symptoms of hay fever in al asthmatic grades usually began after the onset of wheezing, often many years after. Many children with mild episodic asthma

TABLE I-Occurrence of Hay Fever in relation to Asthma in Controls and Four Grades of Asthmatic Children. Results expressed as Proportions of Children

\begin{tabular}{|c|c|c|c|c|c|}
\hline & Controls & Grade A & Grade B & Grade C & Grade D \\
\hline $\begin{array}{l}\text { At any period up } \\
\text { to } 14 \text { years of } \\
\text { age }\end{array}$ & $18 \%$ & $(\mathrm{P} \stackrel{44 \%}{<0.01)}$ & $(P \stackrel{55 \%}{<0.001)}$ & $\left(\mathbf{P} \begin{array}{l}72 \% \\
<0.001)\end{array}\right.$ & $(\mathbf{P} \stackrel{80 \%}{<0.001)}$ \\
\hline $\begin{array}{l}\text { Age at onset: } \\
\text { Under } 6 \text { years } \\
\text { 6-10 Years . } \\
\text { Over } 10 \text { years }\end{array}$ & $\begin{aligned} 4 \% \\
14 \%\end{aligned}$ & $\begin{array}{r}6 \% \\
20 \% \\
18 \%\end{array}$ & $\begin{array}{l}15 \% \\
20 \% \\
20 \%\end{array}$ & $\begin{array}{l}33 \% \\
26 \% \\
13 \%\end{array}$ & $\begin{array}{l}39 \% \\
27 \% \\
14 \%\end{array}$ \\
\hline $\begin{array}{l}\text { Age at last episode: } \\
\text { Under } 12 \text { years } \\
\text { Over } 12 \text { years } \\
\text { Maximum }\end{array}$ & $\begin{array}{r}1 \% \\
17 \%\end{array}$ & $\begin{array}{r}2 \% \\
\mathbf{4 2} \%\end{array}$ & $\begin{array}{r}4 \% \\
51 \%\end{array}$ & $\begin{array}{r}3 \% \\
69 \%\end{array}$ & $\begin{array}{r}7 \% \\
73 \%\end{array}$ \\
\hline $\begin{array}{ll}\text { severity: } & \\
\text { Mild } & \ldots \\
\text { Moderate } & \ldots \\
\text { Severe } & \ldots\end{array}$ & $\begin{array}{r}7 \% \\
11 \%\end{array}$ & $\begin{array}{r}22 \% \\
20 \% \\
2 \%\end{array}$ & $\begin{array}{l}22 \% \\
30 \% \\
3 \%\end{array}$ & $\begin{array}{r}22 \% \\
42 \% \\
8 \%\end{array}$ & $\begin{array}{r}14 \% \\
60 \% \\
6 \%\end{array}$ \\
\hline
\end{tabular}

TABLE II-Occurence of Eczema in relation to Asthma. Results expressed as Proportion of Children

\begin{tabular}{|c|c|c|c|c|c|}
\hline & Controls & Grade A & Grade B & Grade C & Grade D \\
\hline $\begin{array}{l}\text { At any period up } \\
\text { to } 14 \text { years of } \\
\text { age } \ldots\end{array}$ & $11 \%$ & (N.S.) & $(\mathbf{P} 22 \%$ & $(P \stackrel{56 \%}{<0.001)}$ & $(P \stackrel{67 \%}{<0.001)}$ \\
\hline $\begin{array}{l}\text { Age at onset: } \\
\text { Under } 6 \text { months }\end{array}$ & $4 \%$ & $6 \%$ & $6 \%$ & $33 \%$ & $35 \%$ \\
\hline $\begin{array}{c}2 \text { years } \\
\text { Over } 2 \text { years } \\
\text { Age at last episode: }\end{array}$ & $\begin{array}{l}4 \% \\
4 \%\end{array}$ & $\begin{array}{l}3 \% \\
5 \%\end{array}$ & $\begin{array}{l}8 \% \\
8 \%\end{array}$ & $\begin{array}{l}13 \% \\
10 \%\end{array}$ & $\begin{array}{l}19 \% \\
13 \%\end{array}$ \\
\hline $\begin{array}{l}\text { Under } 8 \text { years } \\
\text { Over } 8 \text { years } \\
\text { Maximum }\end{array}$ & $\begin{array}{l}4 \% \\
7 \%\end{array}$ & $\begin{array}{r}3 \% \\
11 \%\end{array}$ & $\begin{array}{r}9 \% \\
13 \%\end{array}$ & $\begin{array}{l}24 \% \\
32 \%\end{array}$ & $\begin{array}{l}25 \% \\
42 \%\end{array}$ \\
\hline $\begin{array}{ll}\text { severity: } & \\
\text { Mild } & \\
\text { Moderate } & \ldots \\
\text { Severe } & \ldots\end{array}$ & $\begin{array}{l}2 \% \\
9 \%\end{array}$ & $\begin{array}{l}6 \% \\
8 \%\end{array}$ & $\begin{array}{r}3 \% \\
12 \% \\
7 \%\end{array}$ & $\begin{array}{r}8 \% \\
30 \% \\
18 \%\end{array}$ & $\begin{array}{l}14 \% \\
31 \% \\
22 \%\end{array}$ \\
\hline
\end{tabular}

N.S. $=$ Not significant.

TABLE III-Occurrence of Urticaria in relation to Asthma. Results expressed as Proportion of Children

\begin{tabular}{|c|c|c|c|c|c|}
\hline & Controls & Grade A & Grade B & Grade C & Grade D \\
\hline $\begin{array}{l}\text { At any period up } \\
\text { to } 14 \text { years of } \\
\text { age } \begin{array}{lll}. & \cdots\end{array}\end{array}$ & $30 \%$ & $\left(\mathbf{P} \begin{array}{c}55 \% \\
<0.01)\end{array}\right.$ & $(P \stackrel{54 \%}{<00.01)}$ & $\left(P \begin{array}{l}57 \% \\
<0.001)\end{array}\right)$ & $\left(P^{57 \%} \stackrel{\circ}{<0} \cdot 01\right)$ \\
\hline $\begin{array}{l}\text { Age at onset: } \\
\text { Under } 2 \text { years } \\
\text { 2-6 Years } . \\
\text { Over } 6 \text { years . } \\
\text { (Not known). } \\
\text { Age at last episode: }\end{array}$ & $\begin{array}{r}7 \% \\
9 \% \\
11 \% \\
(5 \%)\end{array}$ & $\begin{array}{l}13 \% \\
20 \% \\
16 \% \\
(6 \%)\end{array}$ & $\begin{array}{l}10 \% \\
27 \% \\
16 \% \\
(1 \%)\end{array}$ & $\begin{array}{l}13 \% \\
25 \% \\
17 \% \\
(2 \%)\end{array}$ & $\begin{array}{l}24 \% \\
14 \% \\
19 \%\end{array}$ \\
\hline $\begin{array}{l}\text { Under } 10 \text { years } \\
\text { Over } 10 \text { years } \\
\text { (Not known).. } \\
\text { Maximum }\end{array}$ & $\begin{array}{l}17 \% \\
11 \% \\
(2 \%)\end{array}$ & $\begin{array}{l}29 \% \\
24 \% \\
(2 \%)\end{array}$ & $\begin{array}{l}25 \% \\
28 \% \\
(1 \%)\end{array}$ & $\begin{array}{l}33 \% \\
23 \% \\
(1 \%)\end{array}$ & $\begin{array}{l}29 \% \\
28 \%\end{array}$ \\
\hline $\begin{array}{ll}\text { severity: } & \\
\text { Mild } & \ldots \\
\text { Moderate } & \ldots \\
\text { Severe } & .\end{array}$ & $\begin{array}{r}23 \% \\
7 \%\end{array}$ & $\begin{array}{r}41 \% \\
12 \% \\
2 \%\end{array}$ & $\begin{array}{r}25 \% \\
25 \% \\
4 \%\end{array}$ & $\begin{array}{r}20 \% \\
31 \% \\
6 \%\end{array}$ & $\begin{array}{l}16 \% \\
31 \% \\
10 \%\end{array}$ \\
\hline
\end{tabular}

(grades A and B) had ceased to wheeze before they first developed hay fever. Hay fever, once developed, usually persisted unchanged or became more severe, to 14 years of age.

Eczema, like hay fever, occurred in significantly more children with asthma than controls but, unlike the relation of hay fever to asthma, a significant correlation was found only with the more severe grades of asthma and the moderate and more severe grades of eczema. Eczema commonly began before 2 years of age and often cleared by 8 years. In grade $D$ asthmatic children it usually developed before 6 months, initially was more severe, and often persisted to 14 years of age.

There was a significantly greater incidence of urticaria in each of the grades of asthma compared with the controls (table III). Unlike the relations of hay fever and eczema to asthma the incidence of urticaria was similar in children in each grade of asthma. The more severe form of urticaria, however, tended to be in the more severely affected asthmatic children. The significant difference in the prevalence of urticaria in the asthmatic children compared with the controls was mainly due to the substantial difference in the prevalence of moderate and severe urticaria. Mild urticaria, mainly comprising simple hives of childhood, was relatively common in the control group.

\section{SKIN SENSITIVITY}

The proportion of children who reacted, and to what degree, to each of the three specific allergen extracts at 7,10 , and 14 years of age is shown in tables IV-VI. The proportion who reacted to any of the six standard extracts, including the three mixed extracts, at any stage of the study is shown in table VII. Asthmatic children of all grades were significantly more sensitive than the control children. Children with the more severe and persistent forms of asthma (grades $\mathrm{C}$ and D) reacted at an earlier age, more strongly, and to more specific allergens than the children with mild episodic asthma (grades A and B). Many children with milder asthma first reacted to allergens after their asthma had ceased or had substantially ameliorated (table VII). The asthmatic children also showed skin sensitivity to inhalant allergens much more commonly than to ingested allergens.

TABLE IV-Positive Skin-test Results to Rye-grass Allergen expressed as Proportion of Children

\begin{tabular}{|c|c|c|c|c|c|}
\hline & Controls & Grade A & Grade B & Grade C & Grade D \\
\hline $\begin{array}{c}\text { At } 7 \text { years of age } \\
+ \\
++ \\
+++ \\
\text { At } 10 \text { years of age } \\
++ \\
++ \\
+++ \\
\text { At } 14 \text { years of age } \\
++ \\
++ \\
+++\end{array}$ & $\begin{array}{l}3 \% \\
2 \% \\
1 \%\end{array}$ & $\begin{array}{c}10 \% \\
\text { (N.S.) } \\
5 \% \\
2 \% \\
3 \% \\
7 \% \\
\text { (N.S.) } \\
2 \% \\
2 \% \\
5 \% \% \\
31 \% \\
(P 0.001) \\
14 \% \\
11 \% \\
6 \%\end{array}$ & \begin{tabular}{|c|c|}
$23 \%$ \\
$(P 0.001)$ \\
$2 \%$ \\
$4 \%$ \\
$17 \%$ \\
$28 \%$ \\
$(P<0.001)$ \\
$5 \% \%$ \\
$3 \% \%$ \\
$20 \%$ \\
$32 \%$ \\
$(P<0 \cdot 001)$ \\
$2 \% \%$ \\
$10 \%$ \\
$19 \%$ \\
$19 \%$
\end{tabular} & 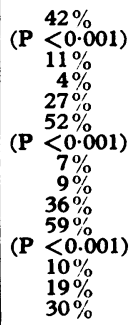 & $\begin{array}{c}\text { (P }<7 \% \\
<0.001) \\
20 \% \\
27 \% \\
60 \% \\
(P<0.001 \\
11 \% \\
18 \% \\
31 \% \\
62 \% \\
\text { (P }<0.001 \\
19 \% \\
19 \% \\
23 \%\end{array}$ \\
\hline
\end{tabular}

TABLE v-Positive Skin-test Results to House-dust Allergen expressed as Proportion of Children

\begin{tabular}{|c|c|c|c|c|c|}
\hline & Controls & Grade A & Grade B & Grade C & Grade D \\
\hline At 7 years of age & $1 \%$ & $(P<0.01)$ & $(P \stackrel{13 \%}{<0.01})$ & $\left(P^{21 \%} \%\right.$ & $\left(P<\frac{47 \%}{<0.001)}\right.$ \\
\hline+ & $1 \%$ & $7 \%$ & $\begin{array}{l}6 \% \\
2 \%\end{array}$ & $\begin{array}{l}7 \% \\
6 \%\end{array}$ & $20 \%$ \\
\hline At 10 years of age & $3 \%$ & $\begin{array}{r}5 \% \\
11 \% \\
\text { (N.S.) }\end{array}$ & $\begin{array}{c}5 \% \\
25 \% \\
(P<0.001)\end{array}$ & $\begin{array}{c}8 \% \\
40 \% \\
(P<0.001)\end{array}$ & $\begin{array}{c}27 \% \\
41 \% \\
(P<0.001)\end{array}$ \\
\hline$\stackrel{+}{++}$ & $2 \%$ & $\begin{array}{l}5 \% \\
3 \% \\
3 \%\end{array}$ & $\begin{array}{l}13 \% \\
10 \% \\
2 \%\end{array}$ & $\begin{array}{l}16 \% \\
16 \% \\
8 \%\end{array}$ & $\begin{array}{c}12 \% \\
27 \% \\
2 \%\end{array}$ \\
\hline At 14 years of age & $3 \%$ & & $\left(\mathbf{P} \begin{array}{l}27 \% \\
<0.001)\end{array}\right.$ & $(P \stackrel{43 \%}{<00.001)}$ & $(P \stackrel{43 \%}{<0.001)}$ \\
\hline $\begin{array}{c}+ \\
++ \\
++\end{array}$ & $\begin{array}{l}2 \% \\
1 \%\end{array}$ & $\begin{array}{r}14 \% \\
6 \%\end{array}$ & $\begin{array}{r}22 \% \\
5 \%\end{array}$ & $\begin{array}{r}29 \% \\
12 \% \\
2 \%\end{array}$ & $\begin{array}{r}39 \% \\
2 \% \\
2 \%\end{array}$ \\
\hline
\end{tabular}


TABLE VI-Positive Skin-test Results of Egg-albumen Allergen expressed as Proportion of Children

\begin{tabular}{|c|c|c|c|c|c|}
\hline & Controls & Grade A & Grade B & Grade C & Grade D \\
\hline $\begin{array}{c}\text { At } 7 \text { years of age } \\
+ \\
++ \\
+++ \\
\text { At } 10 \text { years of age } \\
++ \\
++ \\
+++ \\
\text { At } 14 \text { years of age } \\
++ \\
++ \\
++\end{array}$ & & $\begin{array}{c}3 \% \\
\text { (N.S.) } \\
3 \% \\
\\
2 \% \\
\text { (N.S.) } \\
2 \% \\
\\
2 \% \\
\text { (N.S.) } \\
2 \%\end{array}$ & $\begin{array}{c}4 \% \\
\text { (N.S.) } \\
1 \% \\
2 \% \\
1 \% \\
3 \% \\
\text { (N.S.) } \\
2 \% \\
1 \% \\
3 \% \\
3 \% \\
\text { (N.S.) } \\
2 \% \\
1 \%\end{array}$ & $\begin{array}{c}5 \% \\
\text { (N.S.) } \\
3 \% \\
1 \% \\
1 \% \\
4 \% \\
\text { (N.S.) } \\
1 \% \\
1 \% \\
2 \% \\
4 \% \\
\text { (N.S.) } \\
2 \% \\
2 \%\end{array}$ & $\begin{array}{c}\text { (P } 20 \% \\
7 \% .001) \\
7 \% \\
13 \% \\
9 \% \\
(P<0 \cdot 01) \\
4 \% \\
4 \% \\
5 \% \\
8 \% \\
(P \quad 0.01) \\
3 \% \\
3 \% \\
2 \%\end{array}$ \\
\hline
\end{tabular}

TABLE VII-Positive Skin-test Results to Any One of 6 Standard Extracts used in Study. Expressed as Proportion of Children

\begin{tabular}{|c|c|c|c|c|c|}
\hline & Controls & Grade A & Grade B & Grade C & Grade D \\
\hline At 7 years of age & $4 \%$ & \multirow{4}{*}{$\begin{array}{c}17 \% \\
\text { (N.S.) } \\
16 \% \\
\text { (N.S.) } \\
43 \% \\
48 \% \\
\text { (P <0.001) }\end{array}$} & \multirow{4}{*}{ 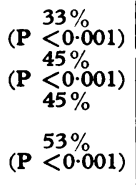 } & \multirow{4}{*}{ 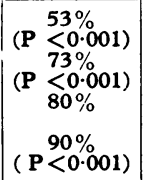 } & \multirow{4}{*}{ 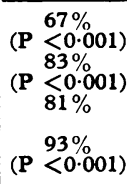 } \\
\hline At 10 years of age & $6 \%$ & & & & \\
\hline \multirow{2}{*}{$\begin{array}{l}\text { At } 14 \text { years of age } \\
\text { At any of the } 3 \\
\text { examinations }\end{array}$} & $10 \%$ & & & & \\
\hline & $15 \%$ & & & & \\
\hline
\end{tabular}

\section{EOSINOPHIL COUNTS}

The mean blood eosinophil count in the four grades of asthmatic children was higher than in the controls (table VIII). The difference was significant in all grades except grade $\mathbf{A}$ at 7 , 10 , and 14 years of age and grade $B$ at 14 years. The mean eosinophil count was progressively higher from grade $A$ to grade $\mathrm{D}$, but there were wide variations in each grade and a substantial proportion of children in each grade, even grade $D$, had counts well within the range of $95 \%$ of the control children. Eosinophilia of $600 / \mathrm{mm}^{3}$ or more was found in $5 \%$ of the controls, in well under half of the total asthmatic population, and in only a little over a half of the grades C and D children (table IX).

The percentage of eosinophils in a nasal smear was higher in children in each of the grades of asthma than in the controls at 7,10 , and 14 years of age, but more particularly at 7 , when asthma for all grades was at its peak frequency (table X). All asthmatic children were less likely to have raised blood or nasal eosinophil counts with increasing age-even grade D children, whose asthma was more persistent and chronic at 14 years. The blood eosinophil count was also lower with increasing age in the control population, an important fact when interpreting eosinophil findings in asthmatic children at different ages.

HISTAMINE BINDING

Differences between asthmatics and controls in their capacity to bind histamine were highly significant (table XI). Parrot et al. (1964) claimed that allergic people could be distinguished by an inability of their serum to bind histamine. There was no substantial difference in the proportion of asthmatic children in each of the grades B, C, and D whose serum failed to bind histamine but in grade $\mathrm{A}$ the proportion was smaller.
TABLE VIII-Mean Blood Eosinophil Count $\left(1 \mathrm{~mm}^{3}\right) \pm$ S.D. in Each Age Group

\begin{tabular}{l|c|c|c|c|c}
\hline & Control & Grade A & Grade B & Grade C & Grade D \\
\hline At 7 years & $308 \pm 258$ & $\begin{array}{c}370 \pm 258 \\
(\mathrm{~N} . \mathrm{S} .)\end{array}$ & $\begin{array}{c}438 \pm 292 \\
(\mathbf{P}<0.01)\end{array}$ & $\begin{array}{c}707 \pm 441 \\
(\mathbf{P}<0.001)\end{array}$ & $\begin{array}{c}927 \pm 485 \\
(\mathbf{P}<0.001)\end{array}$ \\
At 10 years & $238 \pm 162$ & $336 \pm 264$ & $\mathbf{4 2 0} \pm 384$ & $674 \pm 503$ & $\mathbf{7 6 0} \pm \mathbf{4 2 7}$ \\
& $(\mathbf{P}<0.01)$ & $(\mathbf{P}<0.001)$ & $(\mathbf{P}<0.001)$ & $(\mathbf{P}<0.001)$ \\
At 14 years & $213 \pm 250$ & $293 \pm 271$ & $300 \pm 290$ & $554 \pm 369$ & $657 \pm 297$ \\
$($ N.S. $)$ & $(\mathbf{P}<0.05)$ & $(\mathbf{P}<0.001)$ & $(\mathbf{P}<0.001)$ \\
\hline
\end{tabular}

TABLE IX-Eosinophil Counts in Children aged 10 expressed as Proportion of Children

\begin{tabular}{c|c|c|c|c|c}
\hline Count & Control & Grade A & Grade B & Grade C & Grade D \\
\hline $600 / \mathrm{mm}^{3}$ & $5 \%$ & $13 \%$ & $24 \%$ & $51 \%$ & $57 \%$ \\
$800 / \mathrm{mm}^{2}$ & $1 \%$ & $6 \%$ & $15 \%$ & $32 \%$ & $41 \%$ \\
$1,000 / \mathrm{mm}^{3}$ & Nil & $2 \%$ & $8 \%$ & $18 \%$ & $27 \%$ \\
\hline
\end{tabular}

TABLE X-Nasal Eosinophil Count expressed as Proportion of Cells seen in Nasal Smear

\begin{tabular}{|c|c|c|c|c|c|}
\hline $\begin{array}{l}\text { Proportion of } \\
\text { Cells in } \\
\text { Smear }\end{array}$ & Control & Grade A & Grade B & Grade C & Grade D \\
\hline
\end{tabular}

\begin{tabular}{|c|c|c|c|c|c|}
\hline \multirow[b]{2}{*}{$\begin{array}{c}\text { At } 7 \text { years } \\
5 \% \\
20 \%\end{array}$} & \multicolumn{4}{|c|}{-5} & \multirow[b]{2}{*}{$\begin{array}{c}75 \% \\
\text { (P } 22 \% \\
<0.001)\end{array}$} \\
\hline & $\begin{array}{l}8 \% \\
4 \%\end{array}$ & $\begin{array}{c}19 \% \\
7 \% \\
\text { (N.S.) }\end{array}$ & $\begin{array}{c}28 \% \\
(\mathbf{P} \% \% \\
<0.001)\end{array}$ & $\begin{array}{c}64 \% \\
\text { (P }<3 \% \\
<0.001)\end{array}$ & \\
\hline $\begin{array}{c}\text { At } 10 \text { years } \\
5 \% \\
20 \%\end{array}$ & $\begin{array}{l}7 \% \\
4 \%\end{array}$ & $\begin{array}{c}16 \% \\
8 \% \\
\text { (N.S.) }\end{array}$ & $\begin{array}{c}17 \% \\
12 \% \\
(\mathrm{P}<0.05)\end{array}$ & $\begin{array}{c}40 \% \\
17 \% \\
(P<0.001)\end{array}$ & $\begin{array}{c}45 \% \\
\quad 16 \% \\
(P<0.001)\end{array}$ \\
\hline $\begin{array}{c}\text { At } 14 \text { years } \\
5 \% \\
20 \%\end{array}$ & $\begin{array}{l}7 \% \\
1 \%\end{array}$ & $\begin{array}{c}9 \% \\
3 \% \\
\text { (N.S.) }\end{array}$ & $\begin{array}{c}11 \% \\
1 \% \\
\text { (N.S.) }\end{array}$ & $\begin{array}{c}23 \% \\
3 \% \\
(\mathbf{P}<0 \cdot 01)\end{array}$ & $\begin{array}{c}24 \% \\
7 \% \\
(\mathbf{P}<0 \cdot 01)\end{array}$ \\
\hline
\end{tabular}

TABLE XI-Serum Histamine-binding Response at 10 Years of Age expressed as Proportion of Children

\begin{tabular}{|c|c|c|c|c|c|}
\hline & Control & Grade A & Grade B & Grade C & Grade D \\
\hline Negative & $36 \%$ & $54 \%$ & $82 \%$ & $77 \%$ & $86 \%$ \\
\hline $\begin{array}{l}\text { (weak positive) } \\
\text { Positive }\end{array}$ & $\begin{array}{l}15 \% \\
49 \%\end{array}$ & $\begin{array}{c}7 \% \\
39 \% \\
(\mathbf{P}<0 \cdot 05)\end{array}$ & $\begin{array}{c}4 \% \\
14 \% \\
(P<0.001)\end{array}$ & $\begin{array}{c}5 \% \\
18 \% \\
(P<0.001)\end{array}$ & $\begin{array}{c}6 \% \\
8 \% \\
(\mathbf{P}<0.001)\end{array}$ \\
\hline
\end{tabular}

\section{IMMUNOLOGY}

The mean serum IgE level was higher in children in each of the asthmatic grades than in the controls at 10 years of age (table XII). With the exception of the grade $\mathbf{A}$ mean level, which was much distorted by one abnormally high figure, the values were progressively higher in each grade. But, as with the eosinophil counts, there were wide variations and considerable overlap of each of the distributions with the control distribution.

Analysis of frequency distributions at 10 years of age showed that it was impossible to define a discriminant value of serum IgE which was present in most asthmatics and only rarely present in controls (table XIII). Only $55 \%$ of the grade D asthmatics had a serum IgE of above $200 \mathrm{ng} / \mathrm{ml}$, the level in $11 \%$ of controls, whereas almost all grade $\mathrm{D}$ asthmatics showed several other allergic manifestations. Two control children with no other evidence of allergy had a serum IgE of well above $500 \mathrm{ng} / \mathrm{ml}$.

TABLE XII-Mean Serum $I g E \pm S . D$. Results expressed as $n g / m l$

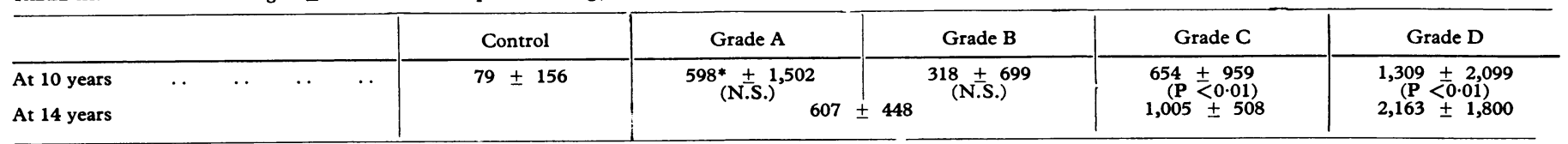

*This high mean value was largely contributed to by one subject with a serum IgE value of over $6,000 \mathrm{ng} / \mathrm{ml}$. 
TABLE XIII-Frequency of IgE Values in Children aged 10 Expressed as Proportion of Children

\begin{tabular}{c|c|c|c|c|c}
\hline IgE Over: & Control & Grade A & Grade B & Grade C & Grade D \\
\cline { 2 - 4 } & $11 \%$ & $20 \%$ & $33 \%$ & $49 \%$ & $55 \%$ \\
$500 \mathrm{ng} / \mathrm{ml}$ & $4 \%$ & $20 \%$ & $15 \%$ & $38 \%$ & $36 \%$ \\
$1,000 \mathrm{ng} / \mathrm{ml}$ & & $16 \%$ & $8 \%$ & $16 \%$ & $18 \%$ \\
\hline
\end{tabular}

\section{Discussion}

These findings throw some light on two important questions. Firstly, is asthma an allergic disorder? Secondly, what is the relation of allergy to asthma?

The most notable finding in the present study was that the asthmatic children in all grades exhibited the manifestations of allergy that were looked for in a significantly greater degree than the controls (see chart), the difference being least in the mild and most marked in the severe grades. Almost all asthmatic children exhibited at least several clinical or laboratory features of the allergic state, and not one exhibited none. We therefore conclude that asthmatics up to 14 years of age have a common allergic immunological disorder as a distinguishing characteristic. The concepts of extrinsic (allergic) and intrinsic asthma and of "wheezy bronchitis" and asthma as separate, distinct entities of asthma in childhood cannot be substantiated.

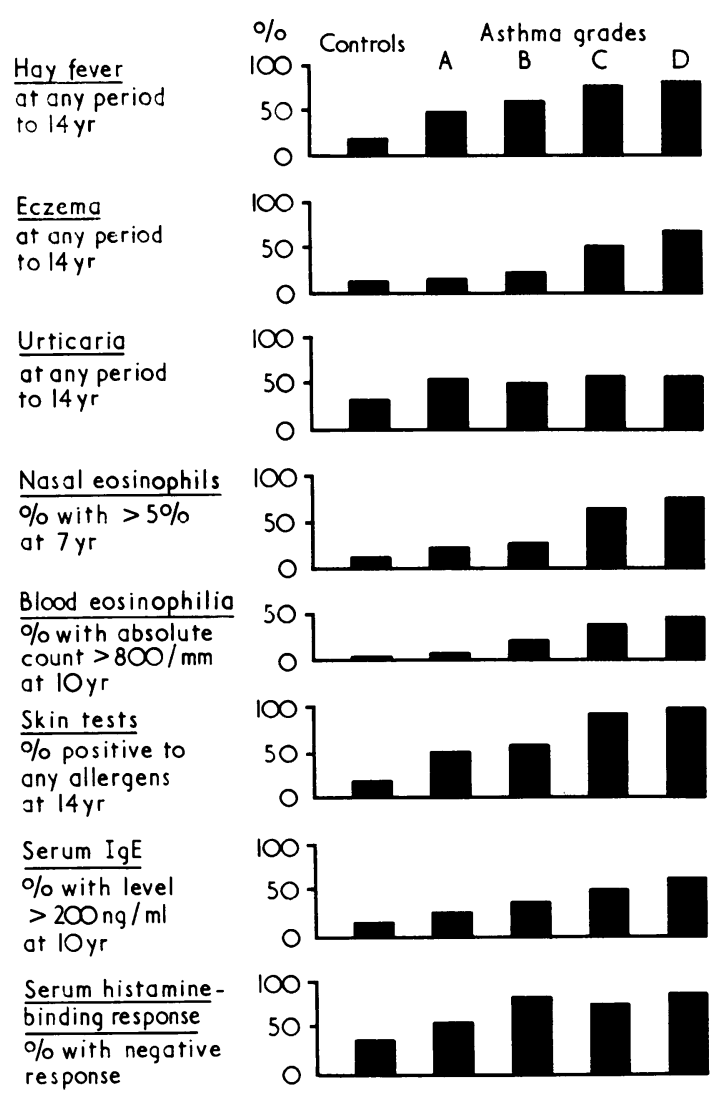

While no single manifestation of allergy unequivocally differentiated the asthmatic from the control children, one-half of the children who had mild and transient asthma and almost all of those with continuing asthma reacted to skin testing with commonly occuring antigens by 14 years of age, the children with more severe asthma reacting to a wider range of allergens.

Comparisons of skin sensitivity tests with radio allergosorbent (R.A.S.) tests, using the same specific allergens, were undertaken on a subgroup of children from the present study (Hogarth-Scott et al., 1973). While the overall correlations between the results of the two methods were good R.A.S. tests showed a greater number of positive reactions to specific allergens. With housedust allergen the disparity between skin testing and R.A.S. tests was substantial, most probably owing to house dust being a mixture of substances. The three extracts of mixed grass pollens, mixed inhalant, and mixed foods also gave fewer and weaker reactions than their component allergens. If the more sensitive R.A.S. tests and a wider range of specific allergens had been used throughout the study probably almost all asthmatic children would have shown a positive response to some allergens by 14 years of age.

While R.A.S. tests showed a high incidence of positive results the total levels of serum IgE did not differentiate the asthmatic from the control population to anything like the same extent. There were higher mean values of total serum IgE in all four grades of asthma as compared with controls, and also a substantial correlation between higher values of $\operatorname{IgE}$ and the grades with the more severe and persistent asthma. It was, however impossible to define values of serum IgE that clearly separated the asthmatic from the control children.

While the histamine-binding capacity of the serum showed highly significant differences between each of the asthma grades and the control group this test did not clearly differentiate the asthmatic children from the controls. The claim by Parrot et al. (1964) that it differentiated the allergic from the normal population is not therefore supported. Thirty per cent. of control children who had no other evidence of allergy failed to show histamine binding, while a number of children with persistent asthma and definite indices of allergy showed a positive histamine binding response.

While some 7-year-old children with asthma showed no evidence to an allergic state almost all did so by the time they were 14 years of age. Probably all asthmatic children if studied adequately throughout childhood would be found to develop evidence of an allergic state.

What is the relationship of allergy to asthma? This study confirmed the well-established relationship between allergy and asthma in children, but it also indicated that allergic factors were not the only cause of asthmatic attacks. Emotional stress, exercise, and other non-specific stimuli were also important in many of the children ( $\mathrm{McNicol}, 1971)$. It was observed, too, that children with less severe asthma, that eased before 10 years of age, often developed a greater range and more pronounced features of allergy by 14 years of age.

While in no way underestimating the importance of allergy in asthma many of the features of asthma cannot be explained on an antigen-reagin basis. A number of studies have established that asthma may be precipitated by a variety of non-allergic factors such as emotion, exercise, different virus infections, laughing, coughing, and non-specific stimuli. Luparello et al. (1968) showed convincingly that asthma may be precipitated within a few minutes and be equally rapidly alleviated by suggestion. Jones and Jones (1966) showed that the bronchi of asthmatic children are hypersensitive to exercise, except severely affected patients with persistent airways obstruction. Horn and Gregg (1973) and McIntosh et al. (1972) have shown how attacks of asthma are often precipitated by a variety of virus infections-mostly by rhino, respiratory syncytial, and parainfluenza viruses.

Bronchial hyperactivity has been increasingly identified as a component of asthma. Jones and Jones (1966) showed that the bronchi of asthmatic subjects who had not had an attack of asthma for three to six years hyperreacted to the stress of exercise, and they suggested that an underlying factor intimately associated with asthma was still present. Blackhall (1970) also established that the bronchi of asthmatic patients who had not wheezed for many years, some for 20 years, were still hyperreactive to exercise. The degree of bronchial hyperractivity depended on the severity of the asthma and also on the time the subject had been free of attacks. Konig et al. (1972) showed that children who had had "wheezy bronchitis" but had been free of attacks for a number of years reacted in a similar way. Cade and Pain (1971) showed that bronchial hyperreactivity to the stimu- 
lus of inhaled methacholine and also non-allergic substances was probably a distinguishing characteristic between asthmatic and control populations.

The relation of bronchial hyperreactivity to allergy is not fully understood. Whether it occurs independently of allergy, is secondary to it, or is often associated with it is unknown. The evidence suggests that probably it is independent of allergy and that it may well he an associated basic disorder in all asthmatic children, the nature of which is at present unknown. In order to define the roles and relation of allergy and bronchial hyperreactivity in asthma a longitudinal population study will be necessary.

This work was partly supported by a grant from the Asthma Foundation of Victoria.

\section{References}

Blackhall, M. I. (1970). Archives of Disease in Childhood, 45, 363.
Cade, J. F., and Pain, M. C. F. (1971). Australian and New Zealand fournal of Medicine, 1,22 .

Freeman, M. (1969). Australian Paediatric fournal, 5, 133.

Gell, P. G. H., and Coombs, R. R. A. (1968). Clinical Aspects of Immunology,

2nd edn. Oxford, Blackwell.
Hogarth-Scott, R. S., Howlett, B. J., McNicol, K. N., Simons, M. J., and Williams, H. E. (1971). Clinical and Experimental Immunology, 9, 571 .

Hogarth-Scott, McNicol, K. N., R. S., Williams, H. E., and Johansson, S. G. D. (1973). Medical fournal of Australia. 1, 1293.

S. G. D. (1973). Medical fournal of Australia. 1, 1293.
Horn, M. E. C., and Gregg, I. (1973). Chest, 63, Supp., p. 44.

Horn, M. E. C., and Gregg, I. (1973). Chest, 63, Supp., p. 44.
Ishizaka, K., and Ishizaka, T. (1970). Annals of Allergy, 28, 189.

Ishizaka, K., and Ishizaka, T. (1970). Annals of Allergy, 28, 189.

Jones, R. H. T., and Jones, R. S. (1966). British Medical fournal, 2, 976. Childhood, 47, 578 .

Luparello, T., Lyons, H. A., Bleecker, E. R., and McFadden, E. R. (1968). Psychosomatic Medicine, 30, 819.

McIntosh, H., et al. (1972). Journal of Allergy and Clinical Immunology, 49, 131 .

McNicol, K. N. (1971). M.D. thesis, University of Melbourne.

McNicol, K. N., and Williams, H. E. (1973a). British Medical fournal, 4, T. Mikol, C., Renoux, M., and Merklen, F. P. (1961). Bulletins et Mémoires de la Société Médicale des Hôpitaux de Paris, 77, 441.

Parrot, J. L., Laborde-Burtin, C., and Saindelle, A. (1964). Annals of Allergy, 22, 511.

Stenuis, B., Wide, L., Seymour, W. M., Holford-Stevens, V., and Pepys, J. (1971). Clinical Allergy, 1, 37.

Vries, K., et al. (1964). In Bronchitis, Second International Symposium, ed. N. G. M. Orie and H. J. Sluiter, p. 167. Assen, Royal Vangorcum.

Williams, H. E., and McNicol, K. N. (1969). British Medical fournal, 4, 321.

\title{
Spectrum of Asthma in Children-III, Psychological and Social Components
}

\author{
K. N. McNICHOL, H. E. WILliaMS, J. ALLAN, I. MCANDREW
}

British Medical fournal, 1973,4, 16-20

\begin{abstract}
Summary
Behavioural disturbances in the child, the mother-child and family relationships, and the family social structure were studied in a representative sample of the whole range of asthmatic children and compared with a control group of normal children. Behavioural disturbances occurred more often and at a statistically significant level only in the small group of children with severe and continuing asthma. These children were those with severe chronic airways obstruction as assessed physiologically and also with the most severe allergic manifestations.

Predominant in the mother-child relations was an over-concern to protect the child's health in those children with continuing asthma at 14 years of age. The families of the very severely affected group of children showed evidence of more stress than other families. Socioeconomic conditions were not significantly different in any group of asthmatic children compared with the control group.
\end{abstract}

\section{Introduction}

Clinicians have long known that emotional stress may either precipitate or aggravate attacks of asthma. Much research in

Clinical Research Unit, Royal Children's Hospital, Melbourne, Australia

K. N. MCNICOL, M.D., Research Fellow

H. E. WILLIAMS, M.D., P.R.A.C.P., Director

H. ALLAN, S.R.N., DIP. Soc. STuD, Medical Social Worker

I. MCANDREW, B.A., DIP. Soc. STUD., Medical Social Worker asthma in children has been directed to the child's personality, parent-child interaction, parental attitudes to the child, and the relation of emotional disturbance to asthma. Asthmatic children have been reported to show a variety of the following characteristics: anxiety, immaturity, lack of self-confidence, dependency, latent aggression, depression, and egocentricity (Rogerson et al., 1935; Gunnarson, 1950; Mansmann, 1952; Creak and Stephens, 1958; Alcock, 1960).

The most commonly accepted hypothesis is that central to the mother-child interaction is a dependency conflict, asthma being precipitated or aggravated by threat of separation (French and Alexander, 1941). Studies of parental attitudes to asthmatic children have indicated a range of attitudes from rejection to over-protection. Miller and Baruch (1948) found that most of the mothers rejected their child. Rees (1956) and Pinkerton (1967) found over-protection more common, while some parents were ambivalent in their attitudes. Rees (1956) also found that a significantly higher number of asthmatic children had an unsatisfactory family life compared to a control group of normal children. There was less stability, security, warmth and affection, and encouragement.

Review of the literature indicates that knowledge of the emotional disturbances and their prevalence in asthmatic children is limited and that there are conflicting views over important questions. It is uncertain whether the disturbances are peculiar to asthma. There are also differences of opinion on whether emotional disturbance is an aetiological factor in asthma or whether it is a sequel.

The main reasons for these differing opinions and deficiencies in knowledge are the wide variations in the aims and methodology of the studies. Few have a sound epidemiological basis, too often the children studied have been from highly selected groups of asthmatics, controls have been lacking, and the clinical, physiological, and allergic state of the patients undefined. Comparisons are therefore impossible. Many have been critically reviewed (Freeman et al., 1964; Feingold et al., 1966).

The present study aimed to determine (i) whether behavioural 